\title{
First report of Perkinsus sp. infecting mangrove oysters Crassostrea rhizophorae from the Brazilian coast
}

\author{
Rachel Costa Sabry ${ }^{1}$, Rafael Diego Rosa ${ }^{2}$, Aimê Rachel Magenta Magalhães ${ }^{3}$, \\ Margherita Anna Barracco ${ }^{2}$, Tereza Cristina Vasconcelos Gesteira ${ }^{1}$, \\ Patricia Mirella da Silva ${ }^{3,4, *}$ \\ ${ }^{1}$ Instituto de Ciências do Mar, Universidade Federal do Ceará, PO Box 52756, Fortaleza, CE, Brazil \\ ${ }^{2}$ Departamento de Biologia Celular, Embriologia e Genética, Universidade Federal de Santa Catarina, PO Box 476 , \\ Florianópolis, SC, Brazil \\ ${ }^{3}$ Departamento de Aquicultura, Universidade Federal de Santa Catarina, PO Box 476, Florianópolis, SC, Brazil \\ ${ }^{4}$ Present address: Núcleo de Engenharia de Pesca, Departamento de Engenharia Agronômica, Centro de Ciências Biológicas \\ e da Saúde, Universidade Federal de Sergipe, Rua Mal. Rondon s/n, Cidade Universitária Prof. José Aloísio de Campos, \\ Jardim Rosa Elze, 49100-000, São Cristóvão, SE, Brazil
}

\begin{abstract}
Protozoan parasites of the genus Perkinsus are considered important pathogens responsible for mass mortalities in several mollusk species worldwide. In the present study we describe for the first time a parasite of the genus Perkinsus infecting the mangrove oyster Crassostrea rhizophorae from the Brazilian coast. Prevalence of this parasite was low in the Pacoti River estuary (Ceará, northeast Brazil) and absent in oysters from southern Brazil. Oyster gill and rectum tissues incubated in Ray's fluid thioglycollate medium (RFTM) revealed the presence of spherical hypnospores (5 to $55 \mu \mathrm{m}$ diam.). Histological analysis showed the occurrence of typical signet-ring trophozoites and schizonts (3 to $6 \mu \mathrm{m}$ diam.) infecting connective tissues of several organs and digestive epithelia. PCR assays specific to the genus Perkinsus, followed by cloning and sequencing of the internal transcribed spacer (ITS) region of the ribosomal ribonucleic acid (rRNA) gene complex, confirmed a close phylogenetic relationship between Brazilian Perkinsus sp. and P. beihaiensis infecting Chinese oysters.
\end{abstract}

KEY WORDS: Crassostrea rhizophorae - Mangrove oyster · Perkinsus sp. · Protozoan parasite · $\mathrm{PCR}-\mathrm{RFLP} \cdot \mathrm{rRNA} \cdot \mathrm{RFTM} \cdot$ Sporulation Resale or republication not permitted without written consent of the publisher

\section{INTRODUCTION}

The state of Santa Catarina in southern Brazil is the country's largest producer $(95 \%)$ of bivalve mollusks (11300 tons in 2007). This activity is of great social and economic importance for the region. The brown mussel Perna perna and the Pacific oyster Crassostrea gigas are the main cultured species, with scallop Nodipecten nodosus and mangrove oyster C. rhizophorae culture existing on a smaller scale. Northeast Brazil has an extensive system of estuaries and mangroves that are inhabited by several oyster populations ( $C$. brasiliana and $C$. rhizophorae). These oysters are widely consumed by local peoples. Accordingly, several attempts have been made to develop native oyster aquaculture in that region, with modest results to date.

In 2003, the Brazilian government started the National Program for Aquatic Animal Health (PNSAA) to help prevent the introduction of exotic animal diseases and to eradicate those already present in the national territory. Guided by this initiative, in 2007 we began a research project to diagnose parasites and dis- 
eases affecting edible and cultured bivalve species from 2 Brazilian regions. The project was designed to survey parasites among wild and cultivated populations of oysters Crassostrea rhizophorae and C. gigas from Santa Catarina Island and the Pacoti River estuary (Fortaleza, in the state of Ceará, northeast Brazil). The results provide data on distributions of pathogens and on host susceptibilities to pathogens, which will qualify further monitoring programs, help avoid disease transfers from infected populations, and inform efforts to keep unaffected areas parasite-free.

The first described parasite of the genus Perkinsus was P. marinus (Mackin et al. 1950), which was identified as being responsible for mortality outbreaks among Crassostrea virginica oyster stocks from Louisiana, USA. It was first described as Dermocystidium marinum, based partly on characteristics of hypertrophic hypnospores and zoosporangia that enlarge among infected oyster tissues when they are incubated in a high-salt formulation of Ray's fluid thioglycollate medium (RFTM) (Ray 1952). Since that time, diverse Perkinsus spp. have been reported to infect many important commercially cultured mollusk species worldwide.

Perkinsus olseni was first described as a pathogen of Australian abalone Haliotis ruber (Lester \& Davis 1981). Azevedo (1989) described the species P. atlanticus infecting the carpet shell clam Ruditapes decussatus in Portugal. P. olseni, which is currently synonymous with $P$. atlanticus, has wide geographic and host ranges. It has subsequently been reported in other bivalve species, such as Pitar rostrata from Uruguay (Cremonte et al. 2005) and $R$. philippinarum, Venerupis pullastra, and Paphia aurea, from the Atlantic and Mediterranean coasts of Spain (Navas et al. 1992, Sagristà et al. 1995, Ordás et al. 2001). However, many of the above studies were based on morphological characteristics, without molecular characterizations. Casas et al. (2002a) described the first use of molecular biology methods to characterize $P$. olseni infecting $R$. decussatus from Spain. Since then, molecular tools have been used to describe and confirm $P$. olseni infecting several bivalve species such as $R$. decussatus from the Mediterranean coast of Spain (Elandaloussi et al. 2009); R. philippinarum from Italy (Abollo et al. 2006), South Korea (Park et al. 2005), and China (Zhang et al. 2005); Protothaca jedoensis from South Korea (Park et al. 2006); Austrovenus stutchburyi from New Zealand (Dungan et al. 2007); and Tridacna crocea from Vietnam (Sheppard \& Phillips 2008).

Since a recent review on perkinsosis (Villalba et al. 2004), in which 6 Perkinsus species ( $P$. marinus, $P$. olseni, P. qugwadi, P. chesapeaki, P. andrewsi, and $P$. mediterraneus) were considered valid, data on the molecular genetics of the species has increased. As a result, improved molecular characterizations show that
P. chesapeaki and $P$. andrewsi are synonymous (Burreson et al. 2005), and 2 additional new Perkinsus species were described: $P$. honshuensis infecting Manila clams in Japan (Dungan \& Reece 2006) and P. beihaiensis infecting Crassostrea hongkongensis, C. ariakensis, and other bivalve hosts from Fujian to Guangxi provinces in southern China (Moss et al. 2008).

Among Brazilian mollusk hosts, Crassostrea rhizophorae is reported as susceptible to Perkinsus marinus after experimental infections (Bushek et al. 2002). Based on RFTM assay results, Littlewood (2000) reported natural infections by $P$. marinus among mangrove oysters C. rhizophorae from Jamaica, although molecular analyses were not used to confirm parasite identity. Therefore, a surveillance program for perkinsosis was initiated along the geographic distribution of this oyster species in Brazilian waters. The present study provides detailed characteristics on the first report of a Perkinsus sp. infection in oysters C. rhizophorae from Brazil. Infections were detected by RFTM assays; parasites were confirmed in situ and characterized by histology; and the pathogen was partially characterized by molecular-genetic methods.

\section{MATERIALS AND METHODS}

Sampling. Adult mangrove oysters Crassostrea rhizophorae were collected at Santa Catarina Island during March and April 2008, and at Fortaleza during August 2008. At Santa Catarina Island, samples were collected in summer, because of the increase in temperature that could favor parasite proliferation. At Fortaleza, samples were collected during winter, because seawater temperature there does not vary during the year (authors' pers. obs.). Oysters were sampled and maintained in tanks with aerated, raw seawater until analysis, for a maximum of $3 \mathrm{~d}$.

At Santa Catarina Island, native oysters were sampled at 2 sites, located on the northern (Sambaqui; $27^{\circ} 29^{\prime} 18^{\prime \prime} \mathrm{S}, 48^{\circ} 32^{\prime} 1^{\prime \prime} \mathrm{W}$ ) and on the southern (Ribeirão da Ilha; $27^{\circ} 42^{\prime} 51^{\prime \prime} \mathrm{S}, 48^{\circ} 34^{\prime} 6^{\prime \prime} \mathrm{W}$ ) bays of the island (Fig. 1). Oysters from Ribeirão da Ilha and Sambaqui inhabited the natural rocky shores of the intertidal zone between 200 and $450 \mathrm{~m}$, respectively, from Crassostrea gigas culture areas.

At Fortaleza, oysters were sampled at 3 different sampling sites located inside the Pacoti River estuary: Site $1\left(3^{\circ} 49^{\prime} 8^{\prime \prime} \mathrm{S}, 38^{\circ} 25^{\prime} 9^{\prime \prime} \mathrm{W}\right)$, Site $2\left(3^{\circ} 49^{\prime} 15^{\prime \prime} \mathrm{S}\right.$, $\left.38^{\circ} 25^{\prime} 10^{\prime \prime} \mathrm{W}\right)$, and Site $3\left(3^{\circ} 49^{\prime} 19^{\prime \prime} \mathrm{S}, 38^{\circ} 25^{\prime} 11^{\prime \prime} \mathrm{W}\right)$, where no Crassostrea gigas oyster culture exists (Fig. 1). The Pacoti River is the most important waterway flowing through the metropolitan region of Fortaleza. The estuary is characterized by the presence of a rich mangrove flora, including Rhizophora mangle, 


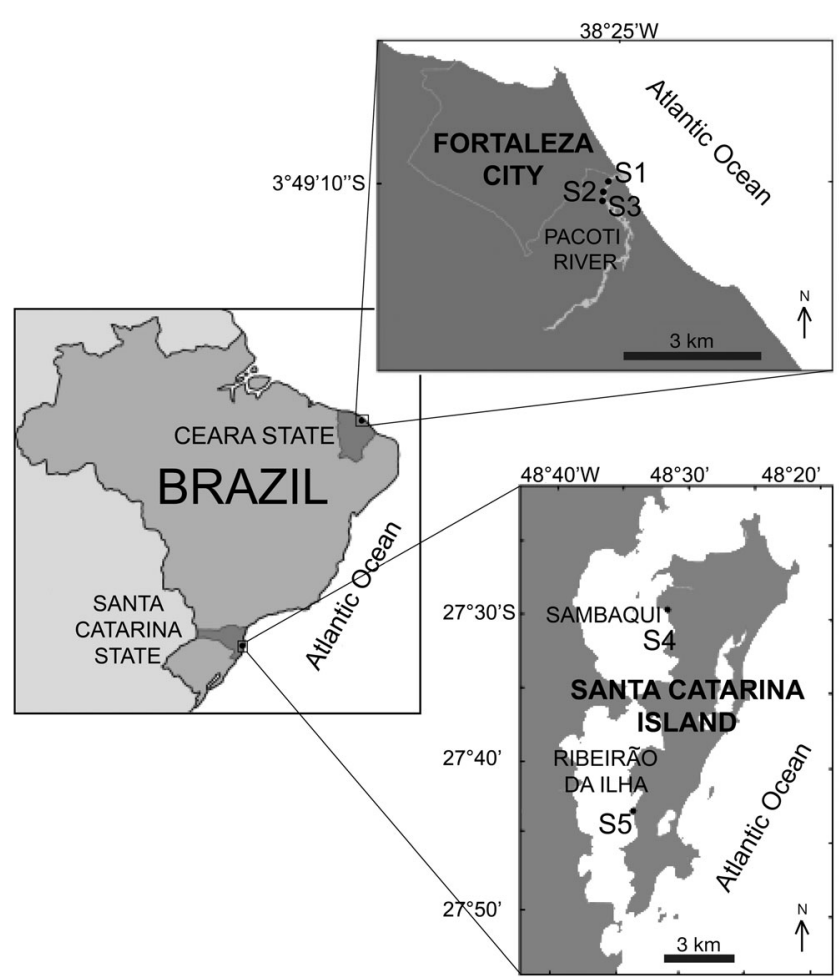

Fig. 1. Oyster sampling sites (S) at Pacoti River estuary (Fortaleza) Santa Catarina Island (Ribeirão da Ilha and Sambaqui)

whose roots form the substrate for natural oyster settlement, from which oysters were collected for the present study.

Seawater temperature and salinity were measured on the day of sampling at each site, near the surface $(0.5 \mathrm{~m})$, using an immersion thermometer and a refractometer, respectively. A total of 150 oysters were analyzed from each site. Oysters $(\mathrm{n}=750)$ were opened, observed for gross abnormalities, and processed using the recommended Office International des Epizooties (OIE) technique for screening Perkinsus sp. using RFTM (OIE 2006). Additionally, tissues from various oysters were randomly or specifically selected for other diagnostic techniques, as follows.

Histological analysis. Among the 150 oysters sampled per site, 30 were randomly selected for histology. Oysters were shucked and a transverse section of $5 \mathrm{~mm}$ thickness including gills, gonad, and digestive tissues was excised and fixed in Davidson's fixative (Shaw \& Battle 1957) for $48 \mathrm{~h}$. Fixed tissues were embedded in paraffin, sectioned at $5 \mu \mathrm{m}$ thickness, and stained with hematoxylin and eosin (H\&E) (Howard et al. 2004).

Detection of Perkinsus sp. by RFTM assays. Oysters collected from each site $(n=150)$ were shucked and the 2 branchial lamellae from one side of the body and the rectum were excised and incubated in RFTM for $7 \mathrm{~d}$ in the dark at room temperature. Samples were prepared for microscopic analysis by individually chopping the RFTM-incubated tissues with a scalpel, adding drops of Lugol's solution on microscope slides, and examining the resulting preparations by light microscopy for dark-stained, spherical Perkinsus sp. hypnospores. The prevalences of Perkinsus sp. infections were estimated as the percentages of infected oysters in each sample $(\mathrm{n}=150)$.

Each oyster was rated using the following infection intensity scale: $0=$ no infection, no hypnospores observed on the whole slide; 1 = very light infection, up to 10 hypnospores observed on the whole slide; $2=$ light infection, from 11 to 100 hypnospores observed on the whole slide; 3 = moderate infection, at least 40 hypnospores observed in each of 10 microscope fields $(40 \times)$ scattered over the tissue; and $4=$ heavy infection, more than 40 hypnospores observed in each of 10 microscope fields $(40 \times)$ scattered over the tissue.

In vitro zoosporulation. Two selected RFTM-positive tissues from an extra August 2008 sampling of Fortaleza oysters were washed twice with filtered sterilized seawater (FSSW) and transferred to culture plate wells containing $2 \mathrm{ml}$ of FSSW. The plates were incubated for 48 to $96 \mathrm{~h}$ at room temperature (approx. $28^{\circ} \mathrm{C}$ ) and examined periodically by light microscopy for zoosporulation.

DNA extraction and PCR assays. Gill tissues from selected oysters were preserved in 95\% ethanol for subsequent extraction of their preserved DNA for use as PCR template samples. Among 150 oysters collected at each of the 2 Santa Catarina Island sample sites, DNA from the gill tissues of the same 30 oysters randomly selected for histological assays were also preserved for PCR assays $(n=60)$. From the 3 samples collected at sites in the Pacoti River estuary near Fortaleza, gill tissues from all 150 oysters from Sites 1 and 3 were preserved for PCR assays, while only the 30 oysters from Site 2 selected for histology were preserved for PCR assays ( $\mathrm{n}=330$ total).

DNA of 29 oysters from Fortaleza was analyzed for Perkinsus sp. by PCR, including 21 that were positive by RFTM assays, 6 that were randomly selected among oysters that were RFTM-negative (2 from each site), and 2 whose tissues were used to confirm zoosporulation induction after RFTM incubation. No samples from Santa Catarina Island were analyzed by PCR, because all of their RFTM assays were negative.

DNA extraction was performed with DNAzol ${ }^{\circledR}$ reagent (Invitrogen) following the manufacturer's protocol. For PCR assays we used PerkITS 85/750 primers that specifically hybridize at conserved regions of the internal transcribed spacer (ITS) region of the ribosomal ribonucleic acid (rRNA) gene complex that are unique to members of the genus Perkinsus (except for P. qugwadi incertae sedis) (Casas et al. 2002a). A posi- 
tive control used $P$. olseni cells isolated in vitro from Galicia, Spain (provided by Dr Antonio Villalba). Negative controls used nuclease-free water instead of template DNA.

PCR reactions were performed in $25 \mu$ reactions containing $1 \mu \mathrm{l}$ (50 to $100 \mathrm{ng}$ ) of genomic sample DNA, PCR buffer at $1 \times$ concentration, $\mathrm{MgCl}_{2}$ at $1.5 \mathrm{mM}$, nucleotides at $0.2 \mathrm{mM}$ each, primers at $0.8 \mu \mathrm{M}$, and 1 unit of Taq DNA polymerase (Invitrogen). The cycling protocol included template DNA denaturation at $94^{\circ} \mathrm{C}$ for $10 \mathrm{~min} ; 35$ amplification cycles of $94^{\circ} \mathrm{C}$ for $1 \mathrm{~min}, 55^{\circ} \mathrm{C}$ for $1 \mathrm{~min}$, and $72^{\circ} \mathrm{C}$ for $1 \mathrm{~min}$; followed by a $72^{\circ} \mathrm{C}$ final extension for $10 \mathrm{~min}$. PCR products were separated on a $1.5 \%$ agarose gel made and bathed in $1 \times$ Tris-EDTA buffer (TE) and stained with ethidium bromide.

PCR-RFLP assays. Perkinsus spp. identification was conducted using restriction fragment length polymorphism (RFLP) assays based on PCR amplification and restriction endonuclease digestions of ITS-region PCR amplicons (Abollo et al. 2006). PCR amplifications were performed as described above, and the restriction reactions were carried out with the enzymes RsaI or HinfI, following the manufacturer's directions (Promega). Briefly, restriction reactions were carried out in a final volume of $20 \mu \mathrm{l}$ containing $3 \mu \mathrm{l}$ of PCR products, $2 \mu \mathrm{l}$ of enzyme buffer, $0.2 \mu \mathrm{l}$ of BSA, and $0.5 \mu \mathrm{l}$ of restriction enzyme (RsaI or HinfI) diluted in sterilized distilled water. The digestions were performed during $2 \mathrm{~h}$ at $37^{\circ} \mathrm{C}$, followed by endonuclease inactivation for $20 \mathrm{~min}$ at $65^{\circ} \mathrm{C}$. To improve visualization of the restriction fragment patterns, $10 \mu \mathrm{l}$ of endonuclease-digested PCR products were resolved on a $6 \%$ non-denaturing polyacrylamide gel stained with ethidium bromide. Restriction profiles from the Perkinsus sp. infection of mangrove oyster Crassostrea rhizophorae $(\mathrm{n}=7)$ were compared with those described for other Perkinsus species (Abollo et al. 2006) as well as with those from $P$. olseni isolate DNA. Restriction profiles expected by digestion of the ITS region of Perkinsus sp. DNA with RsaI or HinfI were determined using Restriction Mapper v.3.0 software (http://www.restrictionmapper.org).

Molecular cloning, DNA sequencing, and phylogenetic analysis. Freshly amplified PCR products of the ITS region from the Perkinsus sp. of 2 infected oysters Crassostrea rhizophorae were cloned into a pCR 2.1 TA cloning vector, using a TA cloning kit (Invitrogen). The positive recombinant clones were identified by colony PCR with the M13 vector primers (Invitrogen), and 1 bacterial colony of each sample was sequenced in both directions. Sequencing was performed in an automated MegaBace 1000 DNA Analysis System, using the DYEnamic ET Dye Terminator kit (GE Healthcare).
The Perkinsus sp. ITS sequences obtained were subjected to BLASTN searches (Altschul et al. 1997) against sequences from the National Center for Biotechnology Information (NCBI). The sequences were aligned with previously reported ITS sequences obtained from the GenBank database, using the Clustal X program (Thompson et al. 1997). GenBank sequences included in the ITS region analysis are given in Table 1. The phylogenetic tree was computed using MEGA 4 software (Tamura et al. 2007) using the maximum parsimony method. Bootstrap values (\%) were calculated from 1000 replicates, and the cut-off value used for a condensed tree was $65 \%$.

\section{RESULTS}

The mean shell heights $( \pm \mathrm{SD})$ of oysters collected from Sambaqui, Ribeirão da Ilha, and Sites 1, 2, and 3 from the Pacoti River estuary were $57 \pm 4.5 \mathrm{~mm}, 55 \pm$ $4.4 \mathrm{~mm}, 58 \pm 8.4 \mathrm{~mm}, 50 \pm 5.4 \mathrm{~mm}$, and $50 \pm 5.2 \mathrm{~mm}$, respectively. The temperatures (and salinities) at those sites were $24.2^{\circ} \mathrm{C}(33.5 \%), 22.0^{\circ} \mathrm{C}(26.5 \%), 30.8^{\circ} \mathrm{C}$ $\left(32 \%\right.$ o, $29.0^{\circ} \mathrm{C}(29 \%)$ and $29.8^{\circ} \mathrm{C}(23.3 \%)$, respectively.

\section{Perkinsus sp. diagnosis by RFTM assays}

The RFTM assay was used as the first and the primary diagnostic technique for Perkinsus sp. All oysters from Sambaqui and Ribeirão da Ilha were negative for perkinsosis in RFTM assays. In contrast, the Pacoti River estuary (Fortaleza) had oysters infected by a Perkinsus sp. Enlarged parasite cells were spherical,

Table 1. GenBank sequences included in the Perkinsus sp. internal transcribed spacer (ITS) region analysis

\begin{tabular}{|ll|}
\hline Species & Accession nos. \\
\hline P. beihaiensis & EF204019, EF204020, EF204021, \\
P. chesapeaki & EU068087, EU068091, EU068092 \\
& AY876302, AY876304, AY876305, \\
P. honshuensis & DQ516696, DQ576316697, DQ516698, \\
& DQ516701, DQ516702 \\
P. marinus & AY295180, AY295188, AY295189, \\
& AY295194, AY295199 \\
P. mediterraneus & AY487834, AY487837, AY487842, \\
& DQ370491, DQ370492 \\
P. olseni & AF441207, AF441209, AF441213, \\
P. qugwadi & AY435092, AY820757 \\
(outgroup taxon) & AF151528 \\
\hline
\end{tabular}


had 5 to $55 \mu \mathrm{m}$ diameters, and were light- or darkstained, depending on the depth of penetration of oxidizing iodine into infected tissue samples (Fig. 2). The mean prevalence of infected oysters from samples from the Pacoti River estuary was $5.78 \%$ (26 of 450) with a range among oyster samples from different sites of 5.3 to $6.7 \%$ (Table 2). Among 26 RFTM-positive oysters, 22 showed very light infection, and 4 (from Sites 1 and 3) showed heavy infection (Fig. 2).

\section{Histological analysis}

Oysters from Santa Catarina Island did not show any trophozoites of Perkinsus sp. infection in histological tissue samples. Samples of oysters from the Pacoti River estuary contained 26 oysters with enlarged hypnospores of Perkinsus sp. after RFTM incubation, but tissues of only 7 of those oysters were fixed and embedded in paraffin for histological analysis (Table 2). Of those 7 oysters, only one (from Site 3; heavily infected by Perkinsus sp. by RFTM) was positive by histological sections, and the remaining oysters (with very light infection by RFTM) did not show any parasite in histological sections. The histologically confirmed Perkinsus sp. infection was characterized by the presence of trophozoites ( 3 to $6 \mu \mathrm{m}$ diam.) and actively proliferating schizonts (4 to $6 \mu \mathrm{m}$ diam.) among the connective tissues (Figs. 3 \& 4) of mantle, labial palps, and digestive gland; although some epithelial cells of digestive tubules were also infected in that oyster. Trophozoites of Perkinsus sp. presented typical signet-ring morphology, with an eccentric vacuole occupying a large area of the cytoplasm, and an

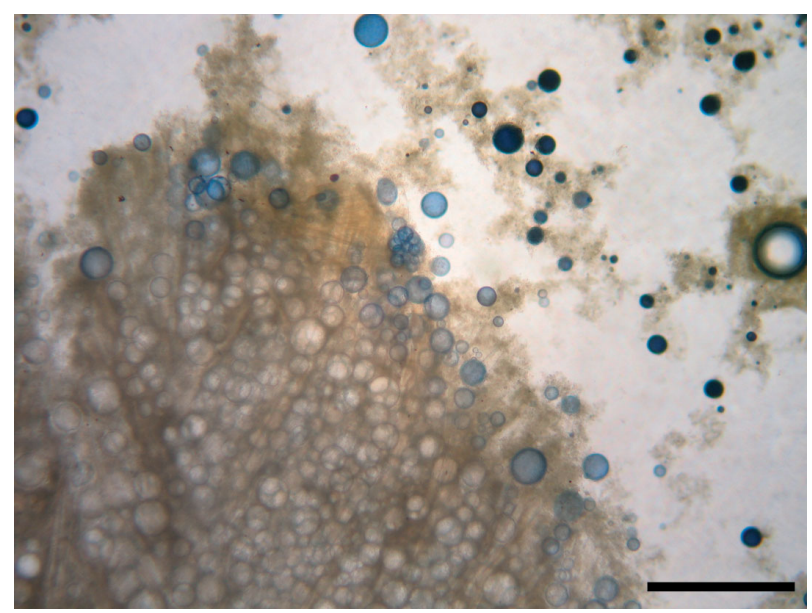

Fig. 2. Low magnification image of numerous enlarged Perkinsus sp. hypnospores from and within gill tissues of a heavily infected Crassostrea rhizophorae after incubation in Ray's fluid thioglycollate medium (RFTM) and staining with Lugol's solution. Numerous hypnospores confined within gill tissues did not come in contact with iodine and remained unstained. Scale bar $=200 \mu \mathrm{m}$

Table 2. Prevalence (\%) of Perkinsus sp. infection among Crassostrea rhizophorae from the Pacoti River estuary (Fortaleza) based on Ray's fluid thioglycollate medium (RFTM) assays and histology. Numbers in parentheses represent positive oysters per total number of samples analyzed by each technique

\begin{tabular}{|lcc|}
\hline Sample site & RFTM & Histology \\
\hline 1 & $5.3 \%(8$ of 150$)$ & $3.3 \%(1$ of 30$)$ \\
2 & $5.3 \%(8$ of 150$)$ & $10.0 \%(3$ of 30$)$ \\
3 & $6.7 \%(10$ of 150$)$ & $10.0 \%(3$ of 30$)$ \\
\hline
\end{tabular}
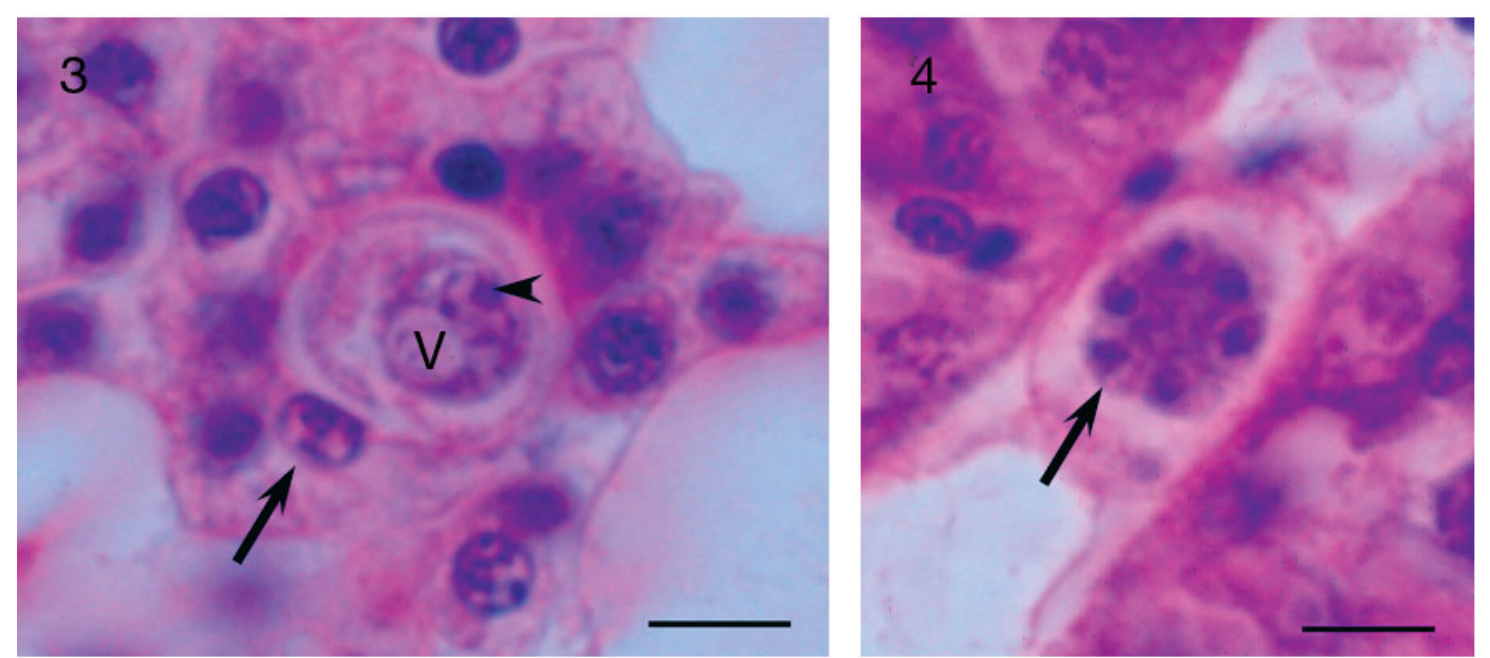

Figs. 3 \& 4 . Perkinsus sp. infecting connective tissues of the mangrove oyster Crassostrea rhizophorae. Fig. 3. Engulfed trophozoite showing typical signet-ring appearance, a large vacuole (V), and an eccentric nucleus with prominent nucleolus (arrowhead). Note: nucleus (arrow) of hemocyte that has phagocytosed the trophozoite. Fig. 4. Perkinsus sp. schizont (arrow) containing small daughter cells in the connective tissue between 2 digestive gland tubules. Hematoxylin and eosin. Scale bars $=5 \mu \mathrm{m}$ 
eccentric nucleus with a patent nucleolus (Fig. 3). Trophozoites and schizonts were systemically seen engulfed by hemocytes (Figs. $3 \& 4$ ), surrounded by an acellular acidophilic matrix, and apparently healthy. Hemocytic infiltration was not associated with parasites. Observations on additional infected oysters are required to comprehensively ascertain the effects of Perkinsus sp. on Crassostrea rhizophorae host tissues.

\section{Parasite zoosporulation}

After 48 to $96 \mathrm{~h}$ of FSSW incubation of RFTMenlarged Perkinsus sp. hypnospores, zoosporulation took place. Various life-stages of parasite were observed, including mature, pre-sporulation hypnospores, zoosporangia showing progressive and proliferative reductive subdivisions of zoosporonts, clusters of sibling zoosporont cells, and mature zoosporangia containing numerous motile zoospores (Figs. 5 to 8).
Only one discharge tube occurred on each zoosporangium (Figs. $7 \& 8$ ). Zoospores $(2 \mu \mathrm{m})$ were observed leaving the discharge tube.

\section{Detection of Perkinsus sp. by PCR}

A total of 26 oysters tested positive for Perkinsus sp. by RFTM assays: 8 from Site 1; 8 from Site 2; and 10 from Site 3. Among those 26 RFTM-positive oysters, 21 had tissue DNA preserved for PCR analysis: 8, 3, and 10 oysters from Sites 1, 2, and 3, respectively. The PerkITS primer pair yielded amplicons of the expected size (687 bp) from 16 of 21 (76\%) samples (Fig. 9), and 5 were negative (2 from Site 1 and 3 from Site 3 ). Assays were repeated twice for negative samples. Oysters that were RFTM-positive and PCR-negative for Perkinsus sp. presented gills with low intensities of infection by RFTM assays. Six RFTM-negative samples ( 2 from each site of the Pacoti River estuary) were also negative by PCR. Two extra samples used for parasite
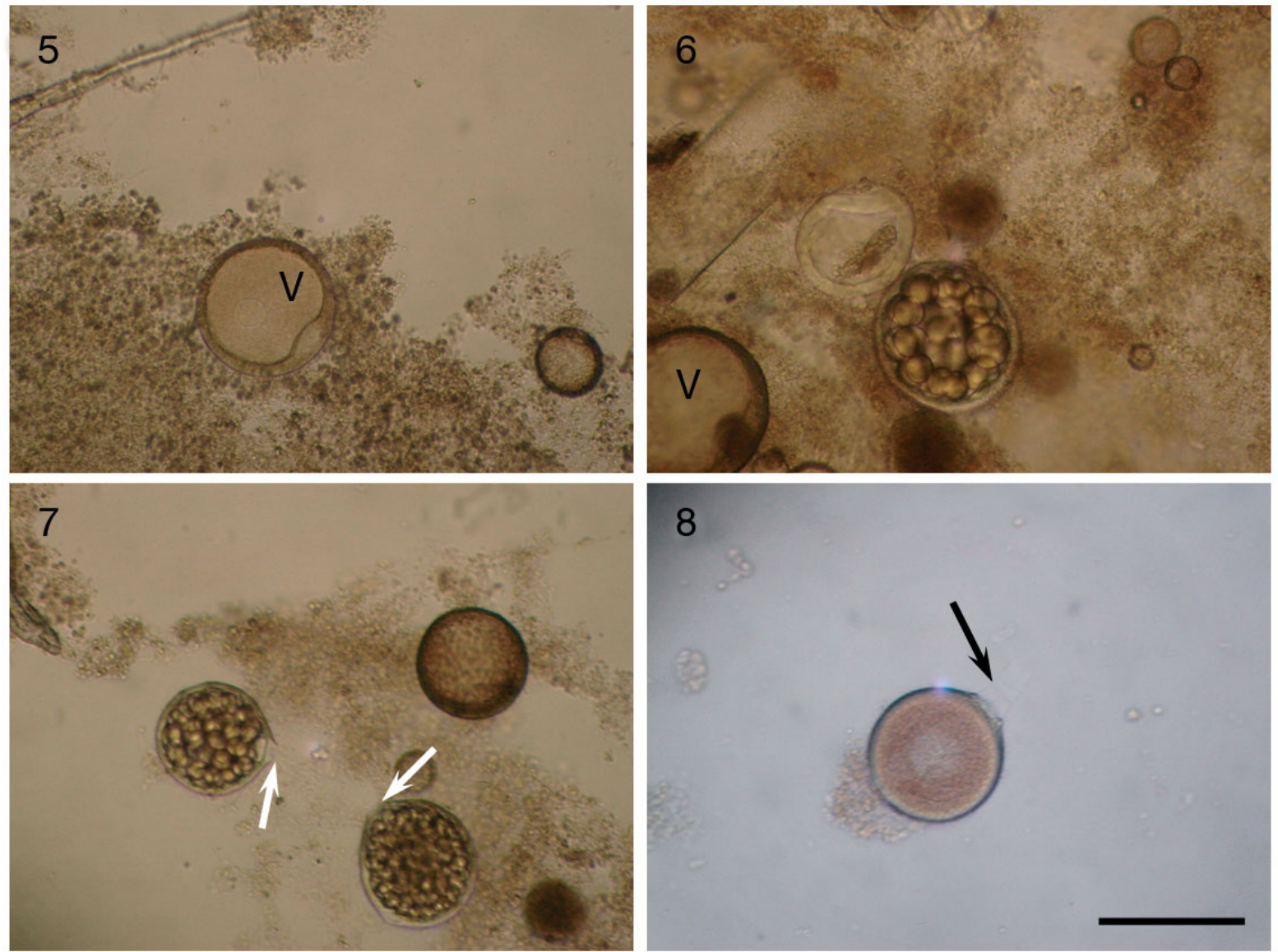

Figs. 5 to 8. In vitro sporulation of Perkinsus sp. in filtered sterilized seawater. Fig. 5. Hypnospore with a large central vacuole (V) and a peripheral nucleus bulging into that vacuole. Fig. 6. Zoosporangium containing approximately 32 subdividing zoosporont cells. Fig. 7. Two zoosporont cells undergoing advanced zoosporulation stages and showing zoosporangium discharge tubes

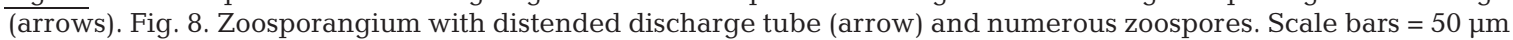


zoosporulation experiments were analyzed by PCR, and both produced positive amplicons.

\section{PCR-RFLP assays}

The RsaI endonuclease produced 3 fragments from PCR amplicons for all 7 of the Crassostrea rhizophorae oysters infected by Perkinsus sp. (Fig. 10). Sizes of those fragments corresponded to approximately 74, 195, and $418 \mathrm{bp}$, as predicted by subsequent sequence analysis. The in vitro isolate of $P$. olseni produced 3 fragments with similar, but not identical, band sizes (Fig. 10).

RFLP patterns from HinfI digestions of PCR amplicons from the Perkinsus sp. that infected Brazilian Crassostrea rhizophorae oysters all contained 5 fragments. Four of those were individually resolved on the polyacrylamide gel at 189, 173, 161, and 153 bp. An additional, nonvisualized, very small fragment (Fig. 10) of $11 \mathrm{bp}$ was predicted by subsequent sequence analysis. In contrast, by similar analysis with the same endonuclease, P. olseni showed only 3 fragments (Fig. 10).

\section{Phylogenetic analysis of rDNA ITS region}

Phylogenetic analysis of the DNA sequences of parasite ITS region were performed to evaluate the taxonomic affinities of the Brazilian Perkinsus sp. The expected ITS region products of $687 \mathrm{bp}$ amplified from
2 PCR-positive Crassostrea rhizophorae oysters were sequenced and compared with corresponding sequences reported for other Perkinsus species. Nucleotide sequences of the ITS region of the Brazilian Perkinsus sp. were deposited in GenBank under accession numbers FJ472346 and FJ472347.

BLASTN searches indicated that the ITS region nucleotide sequences of both Brazilian PCR isolates displayed greatest identity $(97 \%)$ and also showed close similarities to sequences from the ITS regions of other Perkinsus species. Both of the sequences from the Brazilian Perkinsus sp. shared high nucleotide identities $(\sim 98 \%)$ with those of the recently described $P$. beihaiensis infection in Chinese oyster Crassostrea ariakensis and C. hongkongensis (Moss et al. 2008). They were also moderately similar to the ITS region sequences of $P$. mediterraneus $(\sim 87 \%), \quad P$. olseni $(\sim 86 \%)$, P. honshuensis ( 86\%), P. marinus $(\sim 82 \%)$, and $P$. chesapeaki $(\sim 82 \%)$; whereas P. qugwadi (outgroup) showed the lowest homology (<40\%).

Maximum parsimony analysis indicated a close phylogenetic relationship between both Brazilian Perkinsus sp. PCR isolates and P. beihaiensis. The ITS region sequences obtained were grouped with strong support in a monophyletic clade close to $P$. beihaiensis, which is sister to another monophyletic clade containing $P$. olseni, P. marinus, P. mediterraneus, and P. honshuensis. The most distant group from the Brazilian PCR isolates, apart from the $P$. qugwadi outgroup, was P. chesapeaki (Fig. 11).
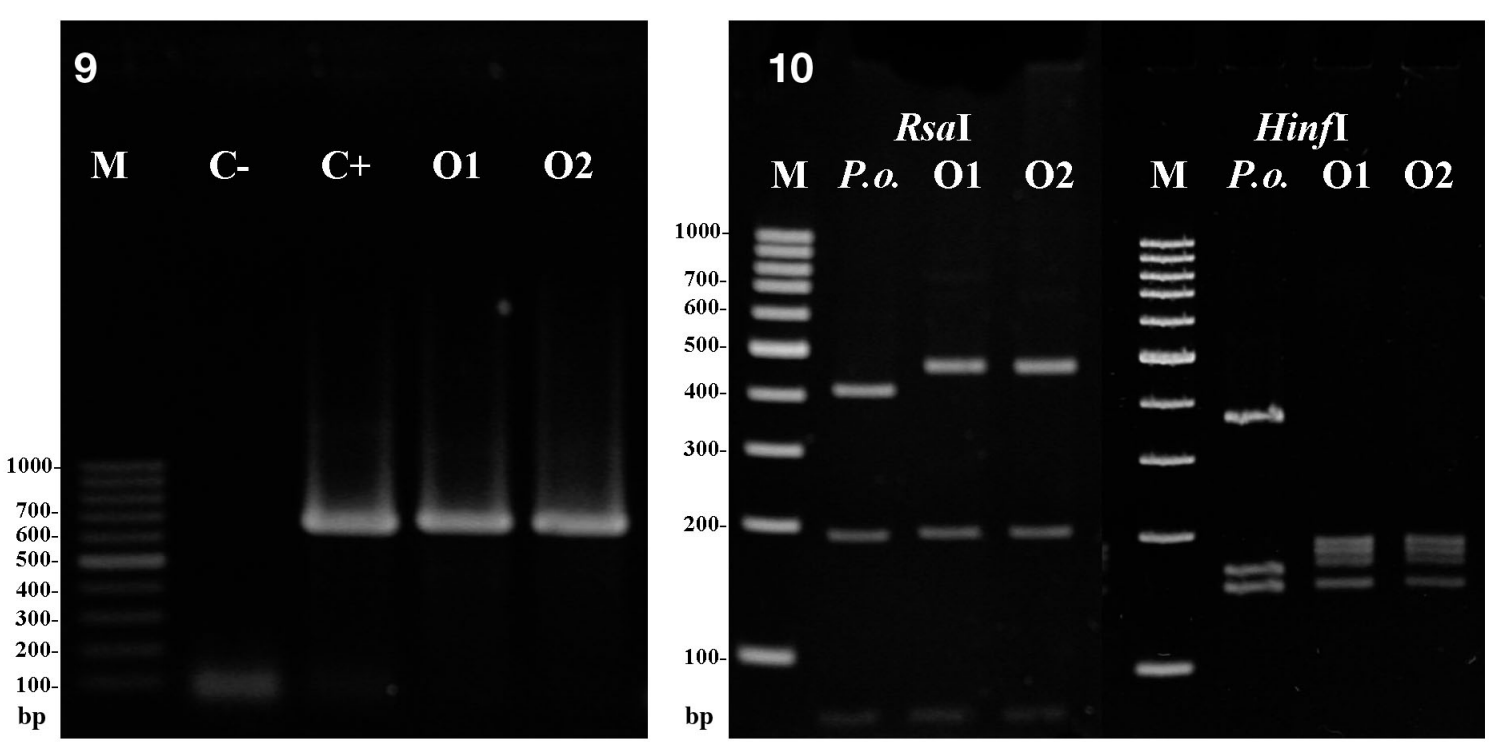

Figs. 9 \& 10. Molecular diagnosis of Perkinsus sp. infecting the mangrove oyster Crassostrea rhizophorae. Fig. 9. rDNA ITSregion PCR for Perkinsus sp. detection. M: 100 bp molecular size markers; C-: negative control (water); C+: positive control (P. olseni isolate DNA); O1: oyster 1 (Perkinsus sp.); O2: oyster 2 (Perkinsus sp.). Fig. 10. PCR-RFLP for differential diagnosis of Perkinsus spp. Fragmentation patterns of PCR-amplified products of the rDNA ITS region from P. olseni (P.o.) and the Perkinsus sp. (O1 and O2) after digestion with RsaI and HinfI endonucleases. See Fig. 9 for abbreviations 


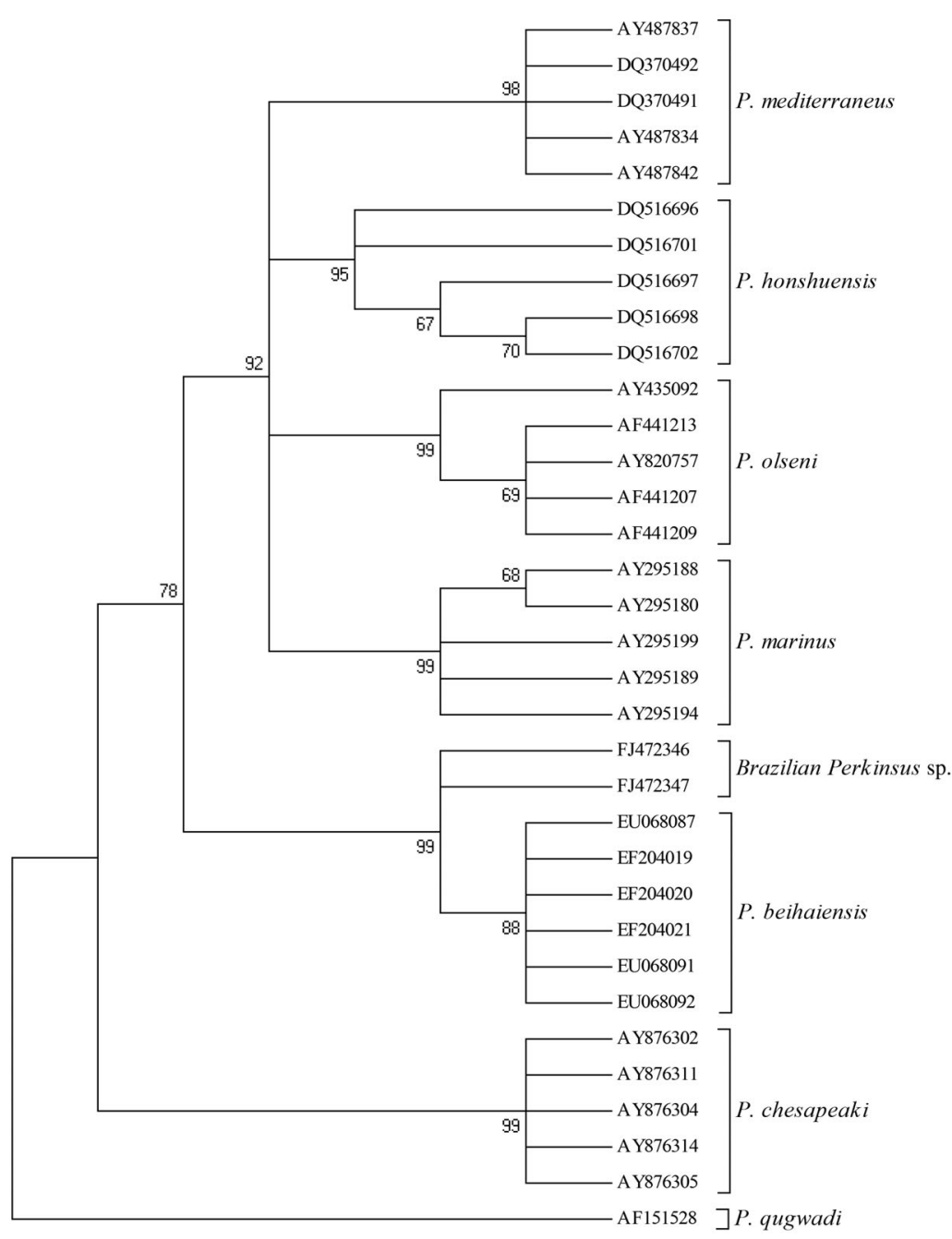

Fig. 11. Maximum parsimony analysis of the rDNA ITS region sequences of different Perkinsus species. Numbers at nodes show bootstrap values (\%) for 1000 replicates

\section{DISCUSSION}

This study describes, for the first time in a Brazilian mollusk, the presence of a protozoan Perkinsus sp. infection in mangrove oysters Crassostrea rhizophorae from the Pacoti River estuary and not detected in oysters from southern Brazil. The parasite was detected by RFTM assays that are reported as a sensitive and reliable diagnostic technique for Perkinsus sp. screening (Reece \& Dungan 2006) and confirmed histologically. PCR assays specific to the genus Perkinsus, followed by cloning and sequencing of ITS region amplicons conserved among known Perkinsus spp. (except $P$. qugwadi sincertae sedis) (Casas et al. 2002a), further confirmed and qualified these findings.

The differences in size between the trophozoites observed in histological sections and the hypnospores observed after incubation of infected tissues in RFTM demonstrate enlargement of trophozoites in RFTM, which is characteristic of Perkinsus spp. (Ray 1954, 1966), except P. qugwadi (Blackbourn et al. 1998). The timing and morphological changes throughout the process of zoosporulation and the morphological characteristics of zoospores are all consistent with observations from other Perkinsus spp. (Sunila et al. 2001, Casas et al. 2002b, Dungan \& Reece 2006, Dungan et al. 2007, Moss et al. 2008).

In histological sections, cells of the Perkinsus sp. infecting Crassostrea rhizophorae were small (3 to $6 \mu \mathrm{m}$ ) and showed the signet-ring morphology typical for members of the genus. Moreover, this Perkinsus sp. showed some similarities with $P$. beihaiensis infection in Chinese oysters (Moss et al. 2008), such as small size, prevalent low-intensity infections, and infection of digestive epithelia. In contrast, epithelia of Japanese clams Ruditapes philippinarum were not typically infected by $P$. honshuensis or P. olseni (Dungan \& Reece 2006), which have nearly exclusive distributions among connective tissues (Dungan et al. 2007). However, pathological consequences of infections among C. rhizophorae from northeastern Brazil may have been underestimated due to the low number of heavily infected oysters (1 of $26,3.85 \%$ ) that were available for histological analysis. Here we report histological results from one heavily infected oyster. Perkinsus beihaiensis caused necrotic lesions among stomach, intestine, and digestive gland epithelia of infected Chinese oysters (Moss et al. 2008).

Phagocytosis is the most important cellular defense mechanism in bivalves, and Perkinsus sp. cells, due to their small size, were found phagocytosed by haemocytes of Crassostrea rhizophorae. However, the response might have been ineffective in killing the parasite, since integral schizonts and trophoites were observed inside phagocytic hemocyte vacuoles. This response is common among oysters infected by P. marinus (La Peyre et al. 1995, Villalba et al. 2004) and was observed in oysters heavily infected by $P$. beihaiensis (Moss et al. 2008). In contrast, $P$. olseni, whose trophozoites are larger, often elicits encapsulation instead of phagocytosis as host reactions against the parasite (Montes et al. 1995, Park \& Choi 2001, Dungan \& Reece 2006).

In the present study, the prevalence of Perkinsus sp. infections was relatively low, and consistent with the fact that no epizootic mortalities occurred among oys- 
ters in the affected populations that were surveyed during this investigation. P. marinus, one of the most harmful species for its host, the eastern oyster Crassostrea virginica in the United States, regularly causes high prevalences of high-intensity infections that result in epizootic seasonal oyster mortalities (RagoneCalvo et al. 2003). In contrast, $P$. marinus infecting $C$. corteziensis in Mexico showed very low prevalences (1 to $6 \%$ ) of typically low-intensity infections (GullianKlanian et al. 2008). P. beihaiensis, which is widespread along the southern China coast, infects at least 2 oyster species at variable prevalences, depending on the site (Moss et al. 2008).

In the present study, PCR assays did not confirm (5 of 21, $25 \%$ ) RFTM-positive cases. The most likely reason for this discrepancy was the generally low intensities of most infections and the small volumes of gill tissues from which the template DNA for PCR assays were extracted and amplified. In our protocol, relatively large volumes of gill tissues were assayed by RFTM assays; while relatively small sub-samples of DNA from those tissues were tested by PCR assays. Similar discrepancies between results of RFTM and PCR assays have been described by others (Reece et al. 2009), and diverse sources of sampling error artifacts that qualify the accuracies of PCR assays have been reviewed, including the effects of focal or localized lesions (Burreson 2008).

Despite the fact that Perkinsus olseni infections are reported in clams Pitar rostrata from neighboring Uruguay (Cremonte et al. 2005), no Perkinsus sp. infections were found among oysters Crassostrea rhizophorae sampled at our survey sites in the major oyster-producing region of southern Brazil, which is located $1360 \mathrm{~km}$ from the Uruguayan capital. The allocation of the Brazilian parasite to the genus Perkinsus was further confirmed when the ITS region was amplified through PCR with genus-specific primers (Casas et al. 2002a). The restriction patterns of the amplified region obtained through digestion with 2 endonucleases allow discrimination between the Perkinsus sp. infection in $C$. rhizophorae from the Brazilian coast from at least 4 Perkinsus spp. (P. marinus, P. chesapeaki, $P$. olseni, and $P$. mediterraneus) whose PCRRFLP profiles are available for comparison (Abollo et al. 2006). Those results indicate that the Perkinsus sp. infecting $C$. rhizophorae does not belong to either the Perkinsus species previously reported in Uruguay $(P$. olseni) (Cremonte et al. 2005), or from the same oyster species in Jamaica (Perkinsus cf. marinus) (Littlewood 2000), although the latter study did not use molecular tools for parasite species identification.

The RsaI endonuclease RFLP pattern of the Brazilian Perkinsus sp. differed slightly from that of $P$. olseni and $P$. mediterraneus, and consistently differed from that of
P. chesapeaki and P. marinus (Abollo et al. 2006). In contrast, the HinfI RFLP pattern of the Perkinsus sp. was only similar with that of $P$. mediterraneus, which also showed 4 fragments (149, 162, 179, and $192 \mathrm{bp})$ (Abollo et al. 2006). Subtle differences between RFLP band patterns obtained from the Brazilian Perkinsus sp., P. olseni (RsaI), and P. mediterraneus (HinfI), were more easily resolved on $6 \%$ polyacrylamide gels than on agarose gels (Abollo et al. 2006). Accordingly, we recommend the use of non-denaturing polyacrylamide gels to improve the sensitivity for differential diagnosis of Perkinsus spp. by PCR-RFLP. However, RFLP alone cannot be used to ascertain parasite identification, especially for a possible new member of the Perkinsus genus. Phylogenetic analysis based on nucleotide sequences of its rDNA ITS region consistently placed the Brazilian PCR isolates within the genus Perkinsus, and revealed high homology with sequences from the recently described $P$. beihaiensis infection of Chinese oysters (Moss et al. 2008). Unfortunately the RFLP pattern for $P$. beihaiensis and $P$. honshuensis and 2 more recently described Perkinsus species could not be included in our analysis, since that DNA was not available for testing.

The maximum parsimony analysis showed that the 2 sequences from the Brazilian Perkinsus sp. formed a distinct monophyletic clade close to the $P$. beihaiensis clade. Nevertheless, to rigorously evaluate apparent phylogenetic relationships that may exist between $P$. beihaiensis and the Perkinsus sp. infection of mangrove oyster Crassostrea rhizophorae will require extended analysis of nucleotide sequences from additional genetic loci.

We concluded that the morphological characteristics observed by light microscopy, such as enlargement in RFTM, the signet-ring appearance of trophozoites, as well as our diverse and consistent molecular genetic results, conclusively support the inclusion of the parasite infecting Crassostrea rhizophorae as a member of the genus Perkinsus. Moreover, some similarities between this Perkinsus sp. and P. beihaiensis, based on histological and molecular-genetic characteristics, suggest a taxonomic affinity. It is surprising that a Perkinsus sp. found in a Brazilian mollusk host would show potential taxonomic affinities with a parasite found in Chinese oysters, rather than with Perkinsus spp. from neighboring regions, including $P$. marinus infecting $C$. virginica in the Gulf of Mexico (Gullian-Klanian et al. 2008) and $P$. olseni infecting Pitar rostrata off the coast of Uruguay (Cremonte et al. 2005). Future challenges include a full description of the Perkinsus sp. infection in Brazilian oyster C. rhizophorae; establishment of in vitro isolate cultures for definitive identification and experimental work; and determinion of the host range, pathological effects, and epidemiology of infections. 
Acknowledgements. The authors are grateful to Dr. A. Villalba from the Centro de Investigacións Marinas (CIMA, Galicia, Spain), who kindly provided preserved Perkinsus olseni isolate cultures. Dr. J. F. Ferreira and shellfish farmer R. C. Rodrigues supplied the oysters. We acknowledge a post-doctoral grant to P.M.S. from the Conselho Nacional de Desenvolvimento Científico e Tecnológico (CNPq), and an Amazônia Azul PhD grant to R.C.S. from the Coordenação de Aperfeiçoamento de Pessoal de Nível Superior (CAPES). This work was supported by MCT/CNPq/MAPA/SDA (No. 64/2008).

\section{LITERATURE CITED}

Abollo E, Casas SM, Ceschia G, Villalba A (2006) Differential diagnosis of Perkinsus species by polymerase chain reaction-restriction fragment length polymorphism assay. Mol Cell Probes 20:323-329

Altschul SF, Madden TL, Schaffer AA, Zhang J, Zhang Z, Miller W, Lipman DJ (1997) Gapped BLAST and PSIBLAST: a new generation of protein database search programs. Nucleic Acids Res 25:3389-3402

Azevedo C (1989) Fine structure of Perkinsus atlanticus n. sp. (Apicomplexa, Perkinsea) parasite of the clam Ruditapes decussatus from Portugal. J Parasitol 75:627-635

Blackbourn J, Bower SM, Meyer GR (1998) Perkinsus qugwadi sp. nov. (incertae sedis), a pathogenic protozoan parasite of Japanese scallops, Patinopecten yessoensis, cultured in British Columbia, Canada. Can J Zool 76:942-953

Burreson EM (2008) Misuse of PCR assay for diagnosis of mollusc protistan infections. Dis Aquat Org 80:81-83

Burreson EM, Reece KS, Dungan CF (2005) Molecular, morphological, and experimental evidence support the synonymy of Perkinsus chesapeaki and Perkinsus andrewsi. J Eukaryot Microbiol 52:258-270

Bushek D, Scarpa J, Laramore SE (2002) Susceptibility of the Caribbean oyster Crassostrea rhizophorae to Perkinsus marinus. (Abstract). J Shellfish Res 21:371-372

> Casas SM, Villalba A, Reece KS (2002a) Study of perkinsosis in the carpet shell clam Tapes decussatus in Galicia (NW Spain). I. Identification of the aetiological agent and in vitro modulation of zoosporulation by temperature and salinity. Dis Aquat Org 50:51-65

Casas SM, La Peyre JF, Reece KS, Azevedo C, Villalba A (2002b) Continuous in vitro culture of the carpet shell clam Tapes decussates protozoan parasite Perkinsus atlanticus. Dis Aquat Org 52:217-231

> Cremonte F, Figueras A, Burreson EM (2005) A histopathological survey of some commercially exploited bivalve molluscs in northern Patagonia, Argentina. Aquaculture 249:23-33

> Dungan CF, Reece KS (2006) In vitro propagation of two Perkinsus spp. parasites from Japanese Manila clams Venerupis philippinarum and description of Perkinsus honshuensis n. sp. J Eukaryot Microbiol 53:316-326

Dungan CF, Reece KS, Moss JA, Hamilton RM, Diggles BK (2007) Perkinsus olseni in vitro isolates from the New Zealand clam Austrovenus stutchburyi. J Eukaryot Microbiol 54:263-270

Elandaloussi LM, Carrasco N, Roque A, Andree K, Furones MD (2009) First record of Perkinsus olseni, a protozoan parasite infecting the commercial clam Ruditapes decussatus in Spanish Mediterranean waters. J Invertebr Pathol 100:50-53

> Gullian-Klanian M, Herrera-Silveira JA, Rodríguez-Canul R, Aguirre-Macedo L (2008) Factors associated with the prevalence of Perkinsus marinus in Crassostrea virginica from the southern Gulf of Mexico. Dis Aquat Org 79: $237-247$

Howard DW, Lewis EJ, Keller BJ, Smith CS (2004) Histological techniques for marine bivalve mollusks and crustaceans, 2nd edn. NOAA Technical Memorandum NOS NCCOS 5

La Peyre JF, Chu FE, Vogelbein WK (1995) In vitro interaction of Perkinsus marinus merozoites with eastern and Pacific oyster hemocytes. Dev Comp Immunol 19:291-304

> Lester RJG, Davis GHG (1981) A new Perkinsus species (Apicomplexa, Perkinsea) from the abalone Haliotis ruber. J Invertebr Pathol 37:181-187

Littlewood DTJ (2000) First report of the protozoan Perkinsus cf. marinus in the Mangrove oyster Crassostrea rhizophorae (Guilding). Caribb J Sci 36:153-154

Mackin JG, Owen HM, Collier A (1950) Preliminary note on the occurrence of a new protistan parasite, Dermocystidium marinum n. sp., in Crassostrea virginica (Gemlin). Science 111:328-329

> Montes JF, Durfort M, García-Valero J (1995) Cellular defence mechanism of the clam Tapes semidecussatus against infection by the protozoan Perkinsus sp. Cell Tissue Res 279:529-538

> Moss JA, Xiao J, Dungan CF, Reece KS (2008) Description of Perkinsus beihaiensis n. sp., a new Perkinsus sp. parasite in oysters of southern China. J Eukaryot Microbiol 55: $117-130$

- Navas JI, Castillo MC, Vera P, Ruiz-Rico M (1992) Principal parasites observed in clams, Ruditapes decussatus (L.), Ruditapes philippinarum (Adams et Reeve), Venerupis pullastra (Montagu) and Venerupis aureus (Gmelin), from the Huelva coast (S.W. Spain). Aquaculture 107:193-199

OIE (Office International des Èpizooties) (2006) Manual of diagnostic test for aquatic animals, 5th edn. OIE, Paris

Ordás MC, Gomez-Leon J, Figueras A (2001) Histopathology of the infection by Perkinsus atlanticus in three clam species (Ruditapes decussatus, $R$. philippinarum and $R$. pullastra) from Galicia (NW Spain). J Shellfish Res 20: 1019-1024

> Park KY, Choi KS (2001) Spatial distribution and infection intensity of the protozoan parasite Perkinsus sp. in the Manila clam Ruditapes philippinarum in Korea. Aquaculture 203:9-22

> Park KI, Park JK, Lee J, Choi KS (2005) Use of molecular markers for species identification of Korean Perkinsus sp. isolated from Manila clams Ruditapes philippinarum. Dis Aquat Org 66:255-263

Park KI, Ngo TT, Choi SD, Cho M, Choi KS (2006) Occurrence of Perkinsus olseni in the Venus clam Protothaca jedoensis in Korean waters. J Invertebr Pathol 93:81-87

> Ragone Calvo LM, Dungan CF, Roberson BS, Burreson EM (2003) Systematic evaluation of factors controlling Perkinsus marinus transmission dynamics in lower Chesapeake Bay. Dis Aquat Org 56:75-86

Ray SM (1952) A culture technique for the diagnosis of infection with Dermocystidium marinum Mackin, Owen, and Collier in oysters. Science 116:360-361

Ray SM (1954) Biological studies of Dermocystidium marinum, a fungus parasite of oysters. Rice Institute pamphlet (Monogr Biol Spec Ser Iss), Rice Institute, Washington, $\mathrm{DC}$

Ray SM (1966) A review of the culture method for detecting Dermocystidium marinum, with suggested modifications and precautions. Proc Natl Shellfish Assoc 54:55-69

Reece K, Dungan C (2006) Perkinsus sp. infections of marine molluscs. In: AFS-FHS Blue Book: suggested procedures 
for detection and identification of certain finfish and shellfish pathogens, 6th edn, Chap 5.2:1-17. Fish Health Section, American Fisheries Society, Bethesda, MD

Reece KS, Dungan CF, Burreson EM (2008) Molecular epizootiology of Perkinsus marinus and P. chesapeaki infections among wild oysters and clams in Chesapeake Bay, USA. Dis Aquat Org 82:237-248

Sagristà E, Durfort M, Azevedo C (1995) Perkinsus sp. (Phylum Apicomplexa) in Mediterranean clam Ruditapes semidecussatus: ultrastructural observations of the cellular response of the host. Aquaculture 132:153-160

Shaw BL, Battle H (1957) The gross and microscopic anatomy of the digestive tract of the oyster Crassostrea virginica (Gmelin). Can J Zool 35:325-347

Sheppard BJ, Phillips AC (2008) Perkinsus olseni detected in Vietnamese aquacultured reef clams Tridacna crocea imported to the USA, following a mortality event. Dis Aquat Org 79:229-235

Editorial responsibility: Eugene Burreson, Gloucester Point, Virginia, USA
Sunila I, Hamilton RM, Dungan CF (2001) Ultrastructural characteristics of the in vitro cell cycle of the protozoan pathogen of oysters, Perkinsus marinus. J Eukaryot Microbiol 48:348-361

Tamura K, Dudley J, Nei M, Kumar S (2007) Mega4: molecular evolutionary genetics analysis (Mega) software version 4.0. Mol Biol Evol 24:1596-1599

Thompson JD, Gibson TJ, Plewniak F, Jeanmougin F, Higgins DG (1997) The Clustal X windows interface: flexible strategies for multiple sequence alignment aided by quality analysis tools. Nucleic Acids Res 25:4876-4882

Villalba A, Reece KS, Ordás MC, Casas SM, Figueras A (2004) Perkinsosis in molluscs: a review. Aquat Living Resour 17: 411-432

Zhang X, Liang Y, Fan J, Zhang W and others (2005) Identification of Perkinsus-like parasite in Manila clam, Ruditapes philippinarum using DNA molecular marker at ITS region. Acta Oceanol Sin 24:139-144

Submitted: April 20, 2009; Accepted: August 25, 2009 Proofs received from author(s): December 7, 2009 